\title{
Samson, wake up! Musical Prague and our recollections ${ }^{53}$
}

\author{
Zuzana Jurková
}

\section{Remembrance as the basis for "me" and "us"}

I walk through Prague with my ears pricked up. I have the feeling that little radars are turning and casting about for snatches of music - music which is sounding around me right now as well as music I had once heard before. I experience the uniqueness of Prague - including the music that can be heard here; uniqueness in the way it combines the global with that which is only typical for Prague. ${ }^{54}$ This combination of the most heterogeneous elements is not coincidental, but functional, satisfying the needs of those who are either permanently or only temporarily ${ }^{55}$ in Prague. And I realize that it is actually this flexibility in satisfying the most varied needs that forms the basis of Prague's cultural identity, ${ }^{56}$ which Assmann calls "the connective structure. It binds man to his neighbor in terms of how the symbolic world of meaning [...] shapes the shared space of experience, expectation and behavior, the connecting and obligating strength of which contributes to the development of confidence and orientation". ${ }^{57}$

According to Assmann, the connective structure has two dimensions: social and temporal. Whereas ethnomusicologists generally deal with the social, i.e., synchronic, this time I'm interested in the temporal aspect. "It binds yesterday with today because it shapes formative recollections and keeps them present; it brings images and histories

53 Research for this article was supported by the Faculty of Humanities, Charles University Prague, Grant SVV 260118/2014.

54 Appadurai, Arjun: Modernity at Large: Cultural Dimensions of Globalization, Minneapolis 1996.

55 Reyes-Schramm, Adelaida: Explorations in Urban Ethnomusicology: Hard Lessons from the Spectacularly Ordinary, Yearbook for Traditional Music, 1982, vol. 14, pp. 1-14.

56 I presume that it is reasonable to think of Prague as a sort of cultural unit. This is the unexpressed assumption of the work of urban anthropologists, including ethnomusicologists.

57 Assmann, Jan: Kultura a pamět', Prague 2001, p. 20. 
from other times close to the advancing horizon of the present, and thus stimulates hope and remembrance [...] Both aspects [...] lay the groundwork for solidarity or identity, enabling an individual to speak about 'us'." 58

In the first part of his remarkable book Cultural Memory and Early Civilization: Writing, Remembrance, and Political Imagination Assmann elaborates in detail his theory of the "culture of remembrance," that is, of the way people cope with "what they mustn't forget". In hiw work he develops the ideas of Maurice Halbwachs (1985) ${ }^{59}$ into the concept of the social construction of memory and remembrances. Memory develops only in the process of socialization; we consider outstanding what others consider outstanding. On the one hand, remembrances arise from individual experiences, but in order for an individual to give them meaning $\mathrm{s} /$ he must incorporate them into social frames of reference. "No memory exists outside of those frames of reference which are used by people living in society to stabilize and again find their remembrances." ${ }^{60}$ That is, an individual can remember only what can be reconstructed as the past within the frame of reference of a given present. On the other hand, "what does not find a frame of reference in similar presents falls into oblivion”. ${ }^{61}$

To emphasize the importance of memory and with it the connected culture of remembrance, Assmann even adds: "Whoever shares it confirms her/his belonging to a group. It is [...] concrete not only in space and time, but, if it can be said so, concrete regarding identity." 62

\section{On the quest for modalities of recollection}

Apart from the almost omnipresence of recollection, a sort of fascination with time, it is, however, more and more obvious to me that the ways used in remembering something are extremely varied. For my material I didn't make do with the division of memory used by historians, ${ }^{63}$ who unsurprisingly proceed from the temporal distance of the remembered event. As a music anthropologist, I ascertain that in the variety of recollections temporal distance does not play either the only or a basic role.

Although collective remembrance is not a particularly frequent subject in ethnomusicology, some of the works of my colleagues have inspired me. Complexly, Philip Bohlman has devoted a long time to the subject of the relation of music to the passing of time. Time in music is actually his key topic. One of his latest texts is a sort of chronicle, a chroni-

\footnotetext{
$58 \quad$ Ibidem, p. 20.

59 Halbwachs, Maurice: Das Gedächtniss und seine soziale Bedingungen, Frankfurt am Main 1985, p. 121 .

60 Ibidem, p. 121. Cited from Assmann, Jan: Kultura a pamět', Prague 2001, p. 36.

61 Ibidem, p. 37.

62 Ibidem, p. 39.

63 For example, Assman (2001) divides memory into communicative and cultural.
} 
cle of returns to the spiritual music of Europe, returns in the sense in which I use the term "recollection": "[...] the past is revisited and revitalized to make the history of the present." ${ }^{64}$ The basic concept of this chronicle is one of the adapted Bakhtin's concepts, that is, chronotop: a characteristic configuration of a certain place and time manifested through music. ${ }^{65}$

If Bohlman's texts can be inspirational to create the "big picture" (and it is sometimes arduous to find data here because of excessively generous formulations), the monograph by Kay Kaufman Shelemay Let Jasmine Rain Down. Song and Remembrance among Syrian Jews is an example of the opposite approach. The initial material of the book is music genre - Pizmonim, ${ }^{66}$ an ethnic group living in New York's Brooklyn - Syrian Jews. By means of various types of analyses (and also texts of other types, mainly historical) the author shows us how the performance of a certain music genre and also the behavior of the members of the community, who are connected to this genre, strengthen the interior ties of the group/community (in regard to the relatively distinctive surroundings) and strengthen their diasporic relations. This is certainly not exceptional for Syrian Jews from Brooklyn. ${ }^{67}$ At the same time it is not the only way of remembering, the only way of looking back. In any case, one basic fact is shown here: the modality of remembering is conditioned by its function, or rather, it reveals that function.

For me, there was another important impulse to reflect on the modalities of recollection - this time from an apparently distant discipline, that is, from narrative psychology. Several authors, e.g. Vladimír Chrz, proceed from the idea that autobiographical narration creates certain complex patterns (Chrz conceptualizes them as "core narration") ${ }^{68}$ which are manifested in various aspects. For an analysis of core narration a few basic categories are essential: subject, acting, values and conviction... ${ }^{69}$ These patterns of penetrating and shaping a narration can be considered an "intratext paradigm" 70 which actually characterizes the concrete narration. At the same time, however, this paradigm - that is, the concrete narration - can refer to "intertext paradigms," or generally shared narrative structures (genres).

\footnotetext{
${ }^{64}$ Bohlman, Philip: Revival and Reconsiliation: Sacred Music in the Making of European Modernity, Lanham 2013, p. XXIII.

65 Ibidem, p. 5.

66 Paraliturgical hymns ... with Hebrew texts on melodies borrowed from Middle Eastern Arabic music. Shelemay, Kay Kaufman: Let Jasmine Rain Down. Song and Rememberance among Syrian Jews, Chicago 1998, p. 1.

67 I understood it in a very similar way when Roma in the Czech Republic sang the so-called phurikane gila. Viz Jurková, Zuzana: Phurikane gilla - kotva identity, Romano džaniben 10, 2003, nr. 3-4, pp. 141-146.

68 Chrz, Vladimír: Možnosti narativního př́stupu v psychologickém výzkumu, Prague 2007, p. 97.

69 Ibidem, p. 98.

$70 \quad$ Ibidem, p. 97.
} 
Anthropologists easily recall examples of the application of a concept originally applied to individuals, to society/community: from the best known example of van Gennep, The Rites of Passage, (1997) adapted by Turner (1969). ${ }^{71}$ Therefore, I have seen in the biographical narrations of individuals the music "recollections" of a community, in particular performances as well as other events connected with music. There are an inexhaustible number of analytic categories present at such events: musicians and listeners and their relation to "remembered" events, the music, its style (and its potential transformation), venue, initiators and a whole complex of publicity... Only with time and with increasing material will the most essential probably become evident.

We have to stop at another question in this introductory part: what is actually the relation between music ${ }^{72}$ and its surrounding "culture," ${ }^{33}$ and specifically the temporal dimension of the connective structure? ${ }^{74}$ In other words: when is music the object of recollection, when is it a medium and when both? A basic ethnomusicological premise states that music reflects social reality, and sometimes it also constitutes it. ${ }^{75}$ My experience shows that music always plays a role in social processes, however small it may be. On the other hand, it may occasionally happen in history (at least Czech) that music itself - its style and performance - has basic social consequences as in the case of the group The Plastic People of the Universe. It is possible that the relation of music to culture can be categorized like a modality of recolletion. However, it seems to me that there is a continuum. Sometimes music did not have an important role in the remembered phenomenon, and in the process of remembering - as one of the media - music acquires a rather arbitrary shape (as in the case of the opera about Milada Horáková). Sometimes the music of the originally remembered phenomenon becomes noticeable and is thus partially a subject of recollection but only as a semiotic sign: in the opera Toufar the priest's singing line contains historical reminiscence. Sometimes the music was a constitutive part of the remembered phenomenon and later it appears, along with its creators, as the bearer of a certain ethos: with Karel Kryl, the singer of protest songs in the time of the so-called normalization, and Michal David, the pro-regime composer of popular music. And in some cases it was the music itself which indeed stimulated social processes, and it is thus the main subject of recollection. In the process of remembering, it of course "surfaced" but its shape changed in various ways.

71 Turner, Victor: The Ritual Process: Structure and Anti-Structure, Hawthorne 1969.

72 Here I use the term music in the anthropological sense: as a musical event including surrounding activities.

73 For this text I consider it sufficient to understand culture as social space which gives meaning to musical sounds and the behavior connected to them.

74 I freely understand connective structure as a synonym for culture.

75 In the words of Mark Slobin: „Annoyed at having social scientists condescendingly grant us the appeal of music as a reflection of social life, nevertheless we have stopped short of claiming it to be highly constitutive of culture and personality. In fact, it can be both, depending on a complex set of variables in given moments." Slobin, Mark: Subcultural Sounds. Micromusics of the West, Wesleyan 2000 , p. 6 . 


\section{Our national heroes}

In the article discussing music recollections of World War II, I labeled one group of events, "our heroes." I vaguely defined it through musical works, in the center of which stands an important historic personality. ${ }^{76}$ Aleš Březina's set of two chamber operas with Soňa Červená in the main role - Zitra se bude... ${ }^{77}$ [Tomorrow There Will Be] and Toufar ${ }^{78}$ correspond well to this characteristic. The former deals with the trial of Milada Horáková and had its premiere on the "Kolowrat" stage of the National Theater in 2008. A film of the same title was made by Jan Hřebejk based on this opera. The subject of the second opera, premiered five years later at the same place (and after the closing of the Kolowrat stage on the New Stage of the National Theater), depicts the communist regime's torture to death of the Roman Catholic priest Josef Toufar.

Opera Toufar (photo: Zuzana Jurková)

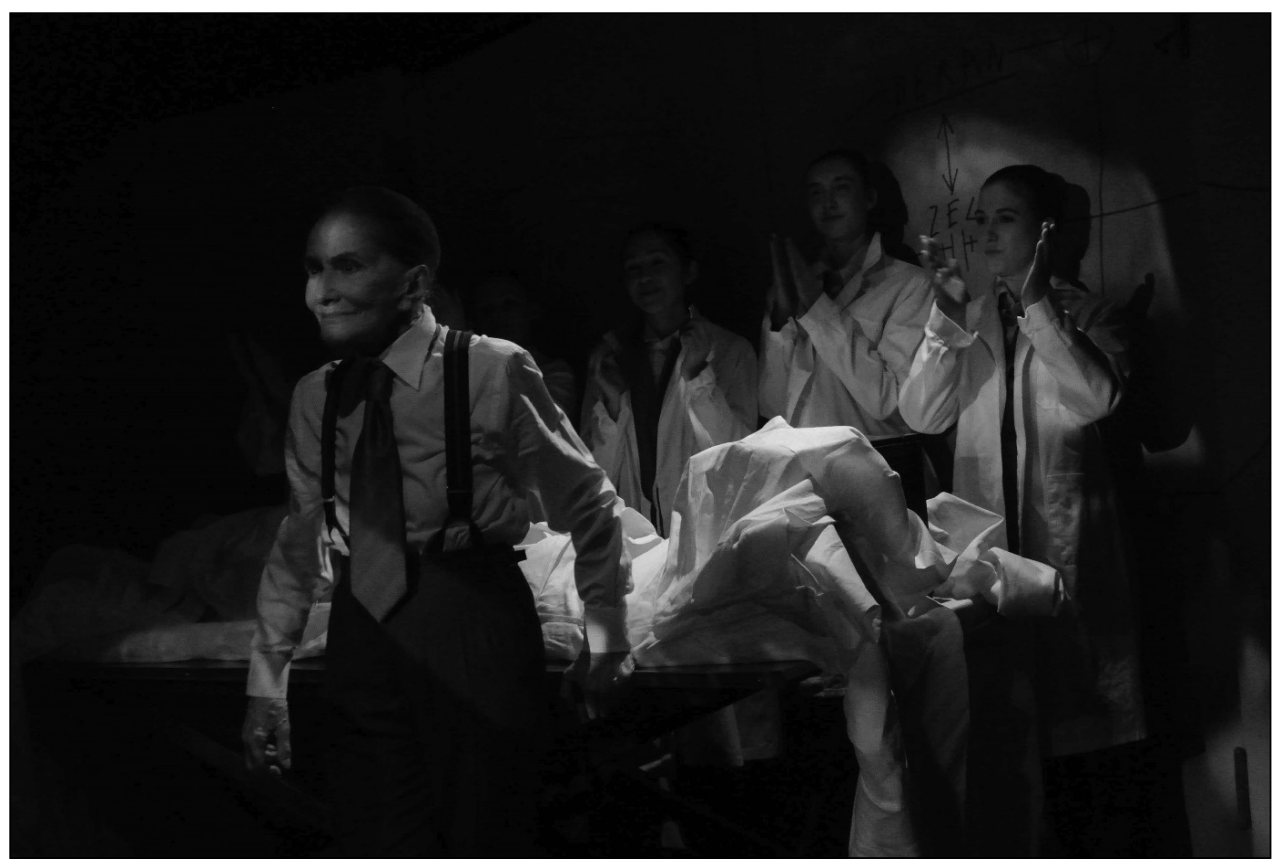

${ }^{76}$ Jurková, Zuzana: De Profundis. Mýtus druhé světové války na pražské hudební scéně, in: B. Soukupová - R. Godula-Węcławowicz (eds.), Mýtus - „realita“ - identita. Národní metropole v čase vyvlastnění, kolaborace a odporu, Prague 2013, p. 163.

77 Premiere April 9, 2008.

78 Premiere on September 18, 2013. The opera was developed in coproduction with the International Theatre Festival of Nitra. 
Apart from the composer of the music, the librettist and the main actor, both works are also similar in their casts (the counter tenor Jan Mikušek, the girls' chorus of the Kühn Children's Choir) and their musical language, which is, to a certain extent, determined by the cast. Without going into detail, one can say that in neither opera does the style pander to a mass audience. Despite this, the first opera had dozens of reprises ${ }^{79}$ - an unthinkable success in comparison to other contemporary music compositions. Undoubtedly, the auditorium was filled not only with contemporary opera lovers; in other words, the work was appealing for more than just artistic reasons and the "soundscape," that is people around the event, is not defined here primarily through music. The basis of that appeal is clearly the figures, "acting" in dramatic (and traumatic) moments of our national history.

This "more-than-just-artistic" meaning is, besides, clearly present in many dimensions: they were the works of a recognized composer, written for an almost legendary singer, directed by foremost directors, performed at the National Theater; they received numerous favorable reactions in specialized and non-specialized media stimulating their future life... One can hardly imagine a contemporary musical work that would reach the entire nation better. As if the adjective "national" directly inspired the name of the whole group: "Our National Heroes", Like some sort of hallmark, "national esteem" can also be understood as the fact that a few protagonists of this category were also awarded state prizes: Milada Horáková (in memoriam) in 1991 from President Václav Havel, Josef Toufar (in memoriam) and Soňa Červená (and also Karel Kryl, remembered later - even twice - in 1996 and 2014) by President Miloš Zeman. ${ }^{80}$

Among the remembrances of "Our national heroes" it is also impossible to exclude those of Karel Kryl (1944-1994). During the times of my youth and as I was growing up, his songs were synonymous with the broadest unofficial culture of resistance. After the revolution his name belonged to the most frequented names in the culture: on bookstore shelves - whether about texts, interviews or publications inspired by Kryl; ${ }^{81}$ on the small stage at the Švanda Theater, where Country Indifference ${ }^{82}$ is performed; in the Czech Republic Parlament on October 7, 2014, a bust of Karel Kryl was unveiled (which provoked

79 See, e.g., http://operaplus.cz/milada-horakova-v-opere-uz-po-padesate/ (November 1, 2014).

Josef Toufar in 2014, Soňa Červená a year earlier.

81 From the momentarily available publications, e.g. Miloš Čermák: Karel Kryl: Pulkacír [Half-heretic], Prague 2013; Miloš Čermák: Nanebevzeti Karla Kryla [Assumption of Karel Kryl], Prague 2014; Vojtěch Klimt: Akorát že mi zabili tátu. Př́běh Karla Kryla [They Just Killed My Father. The Story of Karel Kryl], Prague 2010; Karel Kryl: Človek a jiné prózy [Karel Kryl: The Man and Other Prose], Praha 2013; Ivana Dencevová - Michal Stechlík: Fenomén Karel Kryl [The Phenomenon Karel Kryl], Prague 2014; Karel Kryl: Texty písní [Karel Kryl: Song Texts], Prague 1998; Jaro desáté - Karel Kryl [Tenth Spring - Karel Kryl], sborník k 10. výročí úmrtí Karla Kryla [memorial volume for the 10th anniversary of the death of Karel Kryl], Praha 2004; Karel Kryl: Zemé lhostejnost [Indifferent Land], Prague 2012.

82 Karel Kryl: Země lhostejnost. Konec disentu v Čechách aneb Krylova kocovina ze sametu [Indifferent Land. The End of dissent in Bohemia or Kryl's Velvet Hangover], Director: Dodo Gombár, premiere October 5, 2013. 
a public discussion about whether it was suitable, and whether Kryl would actually have wanted it). In many ways the Karel Kryl 70 concert of April 7, 2014, held in the large hall of Lucerna, was highly symbolic: there was a repeated advertisement on the fourth page in Czech newspapers and on the radio, which was a partner of the event; later on April 15 one of the most popular stations, Radio Journal, broadcast a recording of the concert during prime broadcast time. The most popular pop music stars sang Kryl songs of their own choice at the concert and tickets were sold out in advance. Nevertheless, the reactions of most of the critics could be represented by the headline "Vultures on Kryl." ${ }^{3}$

In the direct broadcast, it is as if we follow the rise of the national heroes's canon set in music, the rise - in Assmann's words - of the musical shape of cultural memory ${ }^{84}$ One of the basic questions connected with such canonization is, „What determines who appears in that canon?" It is evident that - at least at first glance - it is not a question of the „practical,“ apparent imprint of the heroes' lives (nor of their death, although in most cases they have their meanings in the narrated dramas). Nor is the most important factor their brave decision: why, for example, Josef Toufar (to whom, in that dramatic final phase of his life, was not de facto given room to choose), and not Josef Štemberka, also a Roman Catholic priest who bravely decided (!) to die „with his people“ during the massacre of Lidice? ${ }^{85}$

To understand the real variables or conditions for „national canonization“, it will be necessary to gather much more material. But one thing seems clear: none of „Our National Heroes" emerges on an empty, unprepared stage. There is no doubt about the love for Karel Hašler's songs - and even about their specific symbolism during the First Republic. ${ }^{86}$ Karel Kryl was even more important because of the ethos connected with his songs. There is no doubt about the enormous social prestige of Milada Horáková; the fame of her bravery resonated in the unofficial social conscience during the whole period of totalitarianism. By the way, it is symbolic that right after the régime change many streets and squares were named after her, and one of the main ones is in Prague. But how, in the national pantheon of atheist (and to a certain extent anti-Catholic oriented) Czechs, did the Catholic priest Toufar find himself? His profound biography from the pen of the historian Miloš Doležal, Jako bychom dnes zemř́t měli [As if We Should Die Today, 2012], which was awareded the prize Book of the Year 2012 by the newspaper Lidové noviny, is actually the last of those works preparing Toufar's entrée on stage. The book was preceded by the TV documentary In nomine patris (2005) with Viktor Preis,

83 See Lidové noviny April 17, 2014, p. 28. The DVD and CD Karel Kryl 70, Prague 2014 were made from the concert.

84 Assmann, Jan: Kultura a pamět', Prague 2001, pp. 19-28.

85 It is true that Štemberka received a state prize - twice! Nevertheless, his name is more or less unknown to the public and his story has not reached the music scene.

${ }^{86}$ Also see, e.g., Jurková, Zuzana: Aha! To je ta Praha?! „Staropražské písničky“ na prahu mýtu, in: B. Soukupová - M. Hroch - H. Ch. Scheu - Z. Jurková (eds.), Mýtus - „realita“ - identita. Státní a národní metropole po první světové válce, Prague 2012, pp. 175-190. 
a popular actor, in the role of Toufar ${ }^{87}$ The first person from whom the Czech public heard about Toufar's fate was Josef Škvorecký with his novel Mirákl [Miracle]. ${ }^{88}$ It is thus possible to say, along with the discussants in the Lidové noviny Salon, "as if we were even ashamed of heroes". ${ }^{89}$ Nevertheless, our shame is not absolute: we have our heroes and we also create their gallery with the help of works of music.

\section{Underground phenomenon $^{90}$}

It rarely happens in history that music itself, its style or performance - without the political aspirations of musicians - is an agent of social changes. In modern Czech times this is true in only one case: that of the Plastic People of the Universe (PPU) group and the events surrounding it. ${ }^{11}$ The events of the ' 70 s - the police forcibly dispersing the PPU concert in Rudolfov (near České Budějovice) and the subsequent repression, the trials in 1976 and the appearance of Charta 77 - are well known and often described. Like Karel Kryl, the PPU were also in the limelight after 1989. But here the differences were basically more than coincidences. First - neither in the '70s nor after the revolution - it was not just about musicians and their charismatic artistic leader Ivan "Magor" Jirous, but about a much wider community, here called the underground. An extremely varied community of often very active people whose footprints were also noticeable, even in the time of harsh political oppression. ${ }^{92}$ After the revolution their activity did not decline but, on the contrary, intensified - so much so that many of them obtained professional positions which, until then had been denied them for political reasons. The phenomenon of the underground thus acquired very different shapes.

One of them is represented by Guerilla Records, a recording studio in Louny, based on the DIY philosophy typical of the underground. The spiritus agens of Guerilla Records, Vladimír "Lábus" Drápal, publishes on one hand various musical recordings "with

87 See https://www.youtube.com/watch?v=Zo_zFhvTPJY (https://www.youtube.com/watch?v=Zo_ zFhvTPJY) (October 27, 2014).

88 It was first published in Toronto in 1972.

89 Lidové noviny, Oct. 5, 2013, p. 25.

90 This subchapter is named after a Czech TV series (2014); nevertheless, my (narrower) concept does not cover the broader one of the TV series. My understanding of the term "underground" is connected only with the people of the pre-November underground. See Salon Lidových novin, Oct. 11, 2014, pp. VI-VII.

91 The group was of course not isolated; even its members played in other line-ups. Nevertheless there was a court case specifically involving this group, which put into motion other social courses of events leading to Charta 77 . Therefore, the group has an exclusive place in the underground environment.

92 For more details, see mainly Stárek, František Čuňas - Kostúr, Jiří, Baráky: souostroví svobody, Prague 2010. 
underground roots," ${ }^{93}$ but also organizes events of "an underground character." ${ }^{94}$ Let's call this face, where the values of pre-revolutionary underground, such as freedom, authenticity, close relations among people, etc. ${ }^{95}$ can be seen, the true underground.

The working title of the other face of today's underground could be academic. Here I rank the detailed edition of the most varied pre-revolution sources ${ }^{96}$ and new more-orless scientific activities like, for example, the recent Magor conference, ${ }^{97}$ whose proceedings thematized one of the most distinctive figures of the underground, Ivan M. Jirous (1944-2011). By the way, a great number of academic and non-academic events were dedicated to Jirous: besides a complete edition of his writings, recordings of poems read by the author himself were published; ${ }^{98}$ several theatrical performances were inspired by Jirous including a play for children called Magor in Bethlehem at the Theater on the Balustrades - and, of course, the ubiquitous concerts at which the PPU and others usually play... Again we come back to the question that interests me of what influences the choice of those who end up among the figures of the Czech pantheon. This time: why is the scene of recollection dominated by Ivan "Magor" Jirous while, for example, the charismatic Milan "Mejla" Hlavsa, the main composer of the Plastics, who is moreover connected by marriage to the Nermec family, the fundamental formation of the underground, remains far in the background? ${ }^{99}$

Both faces certainly existed and were projected in various ways in the pre-revolutionary underground: the "true" one, for example, in the form of "barracks," 100 the academic one in the persons of the philosophers Jiří Němec a Martin Machovec. The most visible, however, was at the time and still is the artistic, mainly musical, one represented in

93 Do It Yourself - ethos characteristic of (not only musical) expression trying to limit the influence of commerce.

94 It is about both archival recordings of the pre-revolutionary underground and contemporary recordings. For an explanation of their choice, see http://www.guerilla.cz/.

95 The philosophy of Guerilla Records is discussed by V. Drápal in the first part of the television series mentioned above. See http://www.ceskatelevize.cz/porady/10419676635-fenomen-underground/ 414235100221010-underground-is-life/ (Nov. 4, 2014).

96 Jáchym Topol characterizes underground as an attempt to be an archaic tribe, the basis of which is a longing for meetings, as far as possible face to face. See Lidové noviny, Oct. 11, 2014, p. VI.

97 Magorova konference: $k$ dilu I.M. Jirouse [Magor's conference: On the Work of M. Jirous], Edita Onuferová and Terezie Pokorná (eds.), Prague 2014.

98 CD Magorovy labutí písně [Magor’s Swan Songs], Guerilla Records 2011, CD Magorovi ptáci a dalši príběhy [Magor's Birds and Other Stories], Guerilla Records 2012.

99 Hlavsa's personality did not remain completely without reactions, see, e.g., Jan Pelc's book interview with Hlavsa, Bez ohñu je underground [The Underground is without Fires], Prague 2001. On the occasion of the tenth anniversary of Hlavsa's death Zbyněk Petráček calls him a legend. See Lidové noviny, Jan. 5, 2011, p. 14.

100 Stárek, František Čuňas - Kostúr, Jiří: Baráky: souostroví svobody, Prague 2010. 
this text, by the PPU. ${ }^{101,102}$ This group stimulates a whole list of questions from which I will concentrate on only one here: how did the musical language of that key group, i.e. the Plastic People, change? Seen through the eyes of an ethnomusicologist, the change of musical language reveals much more, primarily the change of listeners (who are understood as equivalent stakeholders because "music is played in order to be heard" and also - perhaps mainly - the change of concepts and values, ${ }^{103}$ that is, of ethos.

First, it is necessary to mention one basic fact: while in the ' 70 s and at the beginning of the ' 80 s both the PPU and other groups played, to a certain extent, to a closed public, ${ }^{104}$ nowadays the public, on the contrary, changes along with the change of venue of the performance: once the PPU play in Baráčnická Rychta Pub, once at the National Theater during Stoppard's play, once in the garden of the Ministry of Foreign Affairs on the occasion of the celebration of the State Holiday, and another time at the Archa Theater. In any case that relatively narrow circle of listeners is substantially expanding. A comparison of two recordings of the same piece, the song "Samson" from the cycle Leading Horses, could be a good illustration of the change in the language of music. ${ }^{105}$

This is the last extensive cyclic composition of the group with a total of ten parts; the music was composed (as usual) by Milan "Mejla" Hlavsa; the lyrics of most of the songs were written by Vratislav Brabenec, but the author of the lyrics of "Samson", which we will be concentrating on, was Pavel Zajiček. ${ }^{106}$ The group, at that time larger than usual, played the composition for the first time in March 1981 in Kerhartice near Česká Kamenice, in a former pub owned since 1978 by friends of the underground. The recording, which is

101 I am aware of the wealth of the music scene of the ' 70 s and of the fact that some of its protagonists of the time are still playing. And I am also aware that more and more generations/musicians and listeners profess the underground ethos. A shift of the ethos and the musical language (which reflects a change in the image of the underground and so the process of that memory) meanwhile await more thorough processing.

102 Here I am leaving aside works inspired by the underground. Well known is, for example, Tom Stoppard's Play Rock'n'Roll, performed in the National Theater, in which the PPU participated. For more see Jurková et al, Prague Soundscapes, Prague 2014, p. 165, ff.

103 In his famous analytical model of music, Alan P. Merriam calls the deepest layer "conceptualization". See Merriam, Alan: The Anthropology of Music, Evanston 1964.

104 Martin C. Putna summarized briefly: "[...] despite [...] its plebeianism the underground had little contact with real people; rather between them there was a deep moat". See Lidové noviny, Oct. 11, 2014, p. VI.

105 Comparisons with other parts of the same cycle, e.g., "Fotopneumatická pamět”" [Photopneumatic memory], originally with the harsh solo of Hlavsa, now with the honey voice of Turnová, would lead us to similar conclusions.

106 I take the data about the composition from the text in the booklet of the CD, the author of which is Jaroslav Riedel. See CD The Plastic People of the Universe: Co znamená vésti koně [Leading Horses], Prague 2014. 
the basis of our comparison, was made a month later in Hrádeček at Václav Havel's place. The numerous texts and photo documentation prove how much effort was put into it. ${ }^{107}$

Music can be described in many ways - from very technical (assuming a similar "technical" competence on the part of the reader) to the rather phenomenologically oriented. In this text (whose readers do not necessarily have to be equipped with knowledge of music theory) I will approach the music rather from the latter position.

The whole cycle ushers in a sort of gloomy part, "Leading Horses": to the regular beat of percussion a strange melodic figure is constantly repeated and, after a while, male voices begin singing it: "Next Sunday." It is clear that next Sunday nothing pleasant will happen:

Next Sunday someone else will lead the horses... It will be a holiday of hanging the saints.

In the second part - "It's the Drum's Turn" - a recitation of Brabenec's text is heard on the static sound tracts and at the same time a surrealistic and understandable:

Our Father...thy will be done to play for oneself downbeat on the second

Or both...Let the word sword be the word love...

And after this, a sort of Credo, comes "Samson." One cannot be surprised at its popularity because its base is a non-banal and, at the same time, memorable melody, a text which is both non-platitudinous and striking:

Samson

Wake up

Samson, be strong!

Samson, Samson

Cretins in smithereens...

That striking melody in male voices (which sing in unison making it easy to understand, at the same time without being at all artistic), calling for the Biblical Samson, is well prepared. An instrumental passage precedes it in which first a violin and a viola wander rather melodically aimlessly; later on percussions and a saxophone join them. The harsh feeling of a few dozens of seconds is mainly caused by the sound of stringed instruments: they are played rather roughly, with pressure on the strings and, in addition, without a perfectly clean intonation. ${ }^{108}$ The unpleasant feeling is strengthened by the addition of instruments and by the rising dynamic. And at the moment when we feel it is almost unbearable, we hear that "Samson, wake up!" Yes, yes, finally a relieving call for change. We

107 For more details about the cast and the following publication of the recording, see http://cs.wikipedia. org/wiki/Co_znamen\%C3\%A1_v\%C3\%A9sti_kon\%C4\%9B (Nov. 11, 2014).

108 I am not able to judge how far it is about intention and what can belong to the musical imperfection of the performers. According to the booklet, during the recording the violinist Leština and the drummer Brabec argued that the sound should be more academic; Hlavsa disagreed that "rock'n'roll will not be played academically!" See Riedel, Jaroslav: CD The Plastic People of the Universe: Co znamená vésti koně [Leading Horses], Prague 2014, p. 3. 
follow the melody (which we already more or less remember) and the emotionally recited interpolations interlocking into pauses: "Lean on the columns... Spew out all anger". Then the melody is repeated only by the violin (which is now played more gently) - everything has been said. Layers of the sound coming from various percussions surround it. All the instruments gradually fade until the main melodic figure is heard only in the bells. The sound of each instrument penetrates my soul: the calling for Samson touches me, too. The bells - so seldom used in this style of music - bring about a sort of catharsis.

In 2014 the PPU worked on Leading Horses with the Brno Philharmonic Orchestra. ${ }^{109}$ This was not the first time they played with an orchestra. Two years earlier they performed their Easter Passion Plays with the Chamber Philharmonic Orchestra of Pardubice. This time the project was premiered in Brno, and on March 11 it was presented in the Prague Archa Theater, a favorite place for all sorts of events of the members, friends and supporters of underground. When I was waiting in the glass passage for it to start, I was already somewhat surprised at the variety of people who were there with me. Besides the traditional hippie-types in black polo shirts, jean jackets and stretched out sweatshirts, near me stood, for example, a middle-aged couple, the woman with perfectly trimmed orange-dyed hair. From her conversation I grasped: "I'm curious to see what it will be like." "I think it'll certainly be pleasant." The word "pleasant" surprised me because that is the last adjective I would connect with PPU's music. However, as it turned out, this time it wasn't so inappropriate.

\section{http://youtu.be/6V_G_WFiato}

Excerpt from the performance at Archa, March 11, 2014.

From the video example it is clear how the whole sound was changed. Gone was all the harshness: partly because symphony orchestra musicians simply don't play harshly because harshness does not belong to the sound of an orchestra as we know it, and partly because in the standard orchestral arrangement ${ }^{110}$ every note of the original instruments is connected with other tones of the instrumental group playing in more or less euphonious harmony: instead of the sound of one violin which penetrates deeply into the skin, you hear the whole group of violins (avoiding those individual irregularities caused by one player on one instrument) harmonically in accord with the complementary violins and cellos. The third reason for the loss of the original roughness is the amplification, i.e. electronic intensification, is the following: the sound of the orchestra seems rather unnaturally homogeneous and even the voices of the singers (understandably also amplified so they can be heard above the orchestra) lack the original personal color. One can vindicate Břetislav Rychlík, who characterizes the performance as "monumental and

109 For more about the event see http://www.filharmonie-brno.cz/plastic-people-a-filharmonie-brno-v-unikatnim-projektu,-ktery-se-uz-nebude-opakovat!-p932.html (Nov. 11, 2014).

110 Video of the concert with the Pardubice Philharmonic Orchestra see https://www.youtube.com/ watch?v=O9oT0_niJaA(https://www.youtube.com/watch?v=O9oT0_niJaA (Nov. 11, 2014). 
at the same time dark and uncompromising rock." ${ }^{111}$ Nevertheless, that jangling feeling whereby every tone seems sort of personally right for every listener is gone. The woman from the passage is right: the sound impression is almost pleasant, ${ }^{112}$ in any case it is geared to a much broader audience.

At this point the ethnomusicologist cannot forget the conclusions of Alan Lomax who researched the relation of musical style to culture in global material. Regarding the accompanying instrumental groups he came to the conclusion that "accompanying orchestras of about four or more different types of instrument" (which is the case of the Philharmonic) correspond to a very complex society... "It seems that the formal, instrumental presentation of music appears to be an indicator of increasing social rigidity." 113

\section{Socialist retro: Děti ráje (Children of Paradise)}

The title of the third modality could also contain a component referring to nostalgia: we know a similar term from our neighbors to the northwest, the territory of the former DDR ("eastalgia") or from southern Europe ("Yugonostalgia"). In all cases it is a modality relating nostalgically to the socialist period. On our musical scene it applies exclusively to the field of pop music, and it isn't surprising that its proponents were successful under the totalitarian regime - and, to a certain extent, still are. One example is the musical Déti ráje [Children of Paradise], played from 2009 to 2013. It bore the subtitle "First Czech Hit Musical," which is a Czech variant of the English term jukebox musical, characterizing a stage formation made up of songs composed earlier, and originally having nothing to do with the musical. And indeed, Déti ráje was literally composed of old songs by the prominent socialist hit makers Michal David and, to a lesser extent, František Janeček a Zdeněk Barták. The script writer, producer and one of the performers was Sagvan Tofi, a pop idol of the '80s. It was played four times a week at the GoJa Music Hall, a theater belonging to leading proponents of the socialist music industry, Karel Gott and František Janeček. Despite the relatively high-priced tickets, ${ }^{114}$ the performance had hundreds of reprises $^{115}$ in a relatively large hall; ${ }^{116}$ some of the spectators had discounts because they

\footnotetext{
111 See Lidové noviny, March 11, 2014, p. 10.

112 Even more pleasant, sweeter, is the recording where the PPU play "Samson" with the children's choir Bambini di Praga. See http://www.youtube.com/watch?

113 Lomax, Alan: Folk Song Style and Culture, London 1968, pp. 154-155.

114 The most expensive tickets cost 699 Czech crowns.

115 The official pages of the musical cite 400 reprises: see http://www.detiraje.cz/index.php?main=novinky\&lng $=\mathrm{cz}$ (Nov. 5, 2014).

116 Capacity: 864 seats.
} 
had come at least thirty times. ${ }^{117}$ When Filip Schneider labels Children of Paradise as business with a collective memory, it is evident that the business was very successful.

\section{Dancing children of paradise (photo: Tomáš Martínek)}

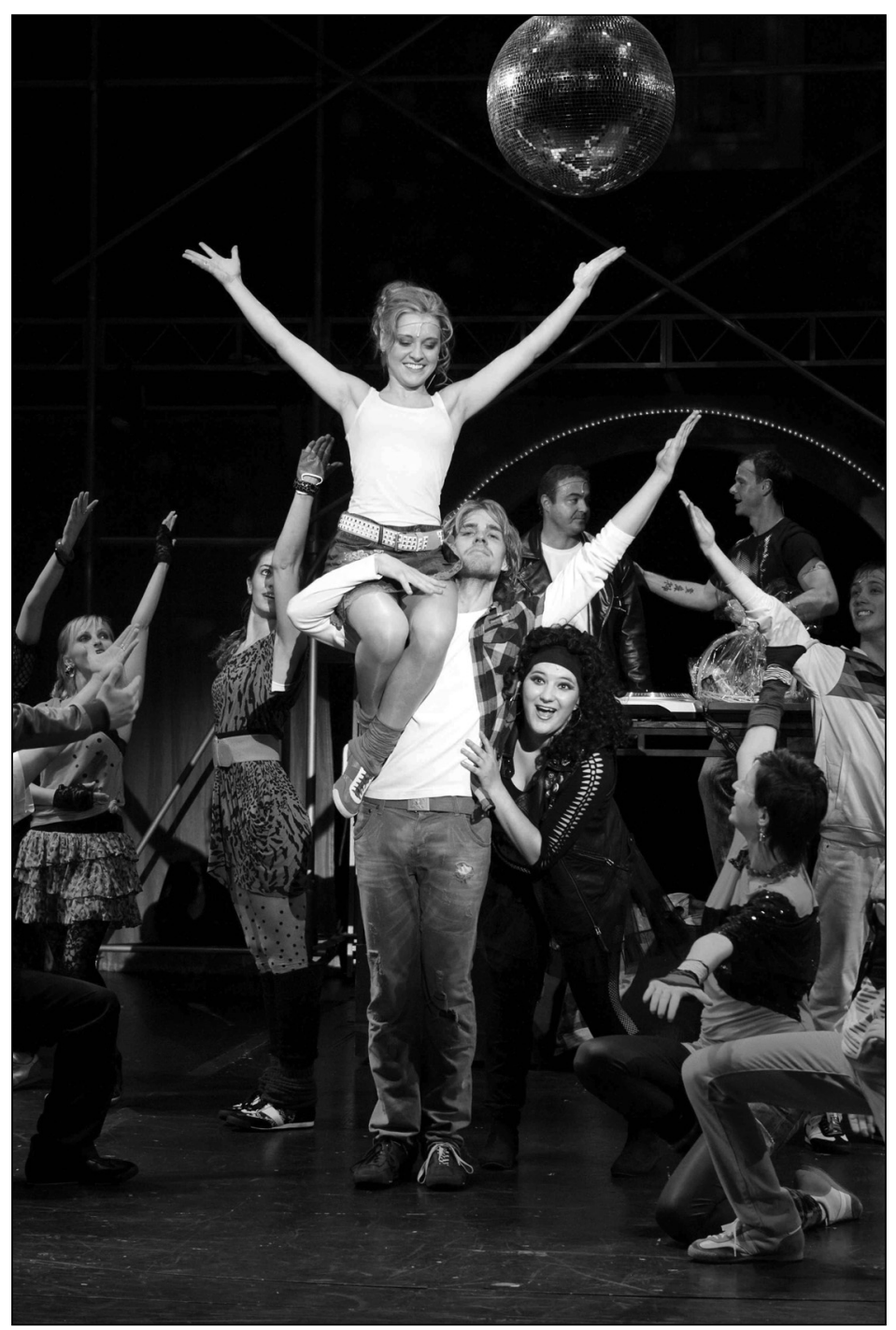

http://www.letniscenaharfa.cz/porad/982-decibely-lasky/

117 I use the data of Filip Schneider, who researched Děti ráje in detail. See Schneider, Filip: Děti ráje - kolektivní pamět jako byznys [Children of Paradise - Collective Memory As Business], in: Z. Jurková et al., Prague Soundscapes. Praha 2014, pp. 181-184. 


\title{
Summary: How do people remember?
}

It is clear that in each of the above-mentioned modalities, different people remember different types of events through different musical language. In the first one, "Our National Heroes", widely accepted creators - be they composers, poets, directors or performers (thus "Our National Creators") - personalities and events having to do with all of the nation, which of course does not mean that the whole nation participates in the recollection. In the second case - the "Underground Phenomenon" - we observe how the members of an originally very closed "archaic tribe" play differently for its "old" listeners and, using a different language, try to address a much broader audience; anthropologically speaking, through our eyes and ears we witness the negotiation of the shapes of music remembrance among the originally narrowly-oriented creators and various types of public. And even though the ethnomusicologist perceives the third case - a musical with the socialist songs of Michal David - as the "seventh circle of hell," ${ }^{118} \mathrm{~s} /$ he stills has the possibility of enjoying the way in which data correspond to theory: the rule on how to make business from music always functions the same way, and crowds of fans of socialist retro correspond well with the social moods as confirmed by the results of recent elections.

\section{Samson, wake up! Musical Prague and our recollections}

\begin{abstract}
The article, based on the long-term research of music events in contemporary Prague, aims to find the ways whereby various Prague communities remember their pasts through music. The theoretical background comes from Jan Assmann (2011), according to whom communities are bound together by the co-called connective structure; its time dimension can be understood as a way of remembrance. In the first part of the article, the author aims to elaborate an analytical approach providing a categorization of types - „modalities“ - of recollection. In the second part, three such modalities created by different communities are presented: an official modality of „national heroes“, the dynamic modality of the underground, and the nostalgic modality of „the children of a socialist paradise“.
\end{abstract}

118 See Pavel Klusák in My žijeme v Praze, a review of Prague Soundscapes (Jurková et al., 2014), Lidové noviny, Sept. 13, 2014, p. X. 


\title{
Samsone, probud' se! Hudební Praha a naše vzpomínání
}

\begin{abstract}
Abstrakt
Článek, vycházející z dlouhodobého výzkumu hudby, provozované v dnešní Praze, se ptá po způsobech, jakým Pražané, resp. různé pražské komunity prostřednictvím hudby zpřitomňují minulost. Východiskem je koncept Jana Assmanna (2011), podle nějž jsou kultury/komunity spojovány konektivní strukturou, která má i svou časovou dimenzi, tedy předmět a způsob vzpomínání. V první části článku se autorka snaží propracovat analytický př́ístup, který by umožňoval kategorizovat typy - „modality“ - vzpomínání. V druhé části pak představuje tři modality, které si vytvářejí různé komunity: oficiální modalitu „národních hrdinů“, dynamickou modalitu undergroundu, a nostalgickou modalitu „dětí socialistického ráje“.
\end{abstract}

\section{Key words}

Ethnomusicology; remembrance; Prague; underground.

\section{Klíčová slova}

Etnomuzikologie; vzpomínání; Praha; underground. 